\title{
DOES MATERNAL SCHOOLING AFFECT THE RISK OF CHILD OBESITY? A PATH ANALYSIS EVIDENCE FROM SURAKARTA, CENTRAL JAVA
}

\author{
Arum Kusuma Rini1), Eti Poncorini Pamungkasari²), Bhisma Murti1) \\ 1)Masters Program in Public Health, Universitas Sebelas Maret \\ 2)Faculty of Medicine, Universitas Sebelas Maret
}

\begin{abstract}
Background: Earlier life-course studies have shown that childhood obesity increases disease risk in adulthood, including metabolic syndrome, cardiovascular disease, type 2 diabetes and its associated cardiovascular, retinal and renal complications, non-alcoholic fatty liver disease, obstructive sleep apnea, polycystic ovarian syndrome, infertility, asthma, orthopedic complications, psychiatric disease, and increased rates of cancer. This study aimed to examine the risk factors of child overweight or obesity in Surakarta, Central Java, using path analysis.

Subjects and Method: This was a case control study carried out in Surakarta, Central Java, from March to April 2018. A sample of 225 primary school students was selected by simple random sampling. The dependent variable was overweight or obesity. The independent variables were maternal education, family income, physical activity, and maternal body mass index (BMI). The data were collected by questionnaire and analyzed by path analysis.

Results: The risk of child overweight or obesity increased with high family income $(\mathrm{b}=1.51 ; 95 \% \mathrm{CI}=0.80$ to $2.22 ; \mathrm{p}<0.001)$ and maternal $\mathrm{BMI} \geq 25(\mathrm{~b}=1.19 ; 95 \% \mathrm{CI}=$ 0.42 to $1.96 ; \mathrm{p}=0.002)$. The risk of overweight or obesity reduced with high physical activity $(b=-1.90 ; 95 \% \mathrm{CI}=-2.63$ to $-1.16 ; \mathrm{p}<0.001)$. Maternal education had indirect association with child overweight or obesity, through maternal BMI and child physical activity.

Conclusion: The risk of child overweight or obesity increases with high family income and maternal BMI $\geq 25$. The risk of overweight or obesity reduces with high physical activity. Maternal education has indirect association with child overweight or obesity, through maternal BMI and child physical activity.
\end{abstract}

Keywords: overweight, obesity, determinants, children, path analysis

\section{Correspondence:}

Arum Kusuma Rini. Masters Program in Public Health, Universitas Sebelas Maret, Jl. Ir. Sutami No. 36 A, Surakarta 57126, Central Java, Indonesia.

Email: arumkusumarini@yahoo.com. Mobile: 082133044191 